University of Nebraska - Lincoln

DigitalCommons@University of Nebraska - Lincoln

1991

\title{
Cadmium Adsorption on Iron Oxides in the Presence of Alkaline- Earth Elements
}

Christina Cowan

Pacific Northwest National Laboratory

John M. Zachara

Pacific Northwest National Laboratory, john.zachara@pnl.gov

Charles T. Resch

Pacific Northwest National Laboratory

Follow this and additional works at: https://digitalcommons.unl.edu/usdoepub

Part of the Bioresource and Agricultural Engineering Commons

Cowan, Christina; Zachara, John M.; and Resch, Charles T., "Cadmium Adsorption on Iron Oxides in the Presence of Alkaline-Earth Elements" (1991). US Department of Energy Publications. 209.

https://digitalcommons.unl.edu/usdoepub/209

This Article is brought to you for free and open access by the U.S. Department of Energy at DigitalCommons@University of Nebraska - Lincoln. It has been accepted for inclusion in US Department of Energy Publications by an authorized administrator of DigitalCommons@University of Nebraska - Lincoln. 


\title{
Cadmium Adsorption on Iron Oxides in the Presence of Alkaline-Earth Elements
}

\author{
Christina E. Cowan, * John M. Zachara, and Charles T. Resch \\ Environmental Sciences Department, Battelle, Pacific Northwest Laboratories, P.O. Box 999, MSIN K3-61, Richland, \\ Washington 99352
}

- Cadmium sorption on $\mathrm{Fe}_{2} \mathrm{O}_{3} \cdot \mathrm{H}_{2} \mathrm{O}(\mathrm{am})$ in the presence of alkaline-earth cations was investigated with emphasis on the $\mathrm{Cd}-\mathrm{Ca}$ binary system. In binary-element sorption experiments with $\mathrm{Ca}, \mathrm{Mg}, \mathrm{Sr}$, and $\mathrm{Ba}$, competition was observed primarily in $\mathrm{Cd}-\mathrm{Ca}$ binary mixtures, which were studied at three ionic strengths $(0.5,0.1$, and $0.005 \mathrm{M})$. The extent of competition increased with increasing $\mathrm{Ca}$ concentration. In single-element experiments changes in ionic strength (between 0.005 and $0.5 \mathrm{M}$ ) did not influence $\mathrm{Cd}$ sorption but did affect $\mathrm{Ca}$ sorption, implying that a portion of the $\mathrm{Ca}$ surface complexes were outer sphere. The triple-layer model (TLM), using inner- and outersphere complexation reactions, and the nonelectrostatic model (NEM), incorporating only one adsorption plane, both adequately represented the adsorption of the individual elements and predicted the $\mathrm{Cd}-\mathrm{Ca}$ competition at ionic strengths of 0.5 and $0.1 \mathrm{M}$. Neither model predicted the competition at $0.005 \mathrm{M}$. The NEM better simulated the shape of the measured $\mathrm{Cd}-\mathrm{Ca}$ adsorption edge at all ionic strengths. The combined experimental and modeling results suggest that $\mathrm{Cd}-\mathrm{Ca}$ competitive adsorption on $\mathrm{Fe}_{2} \mathrm{O}_{3} \cdot \mathrm{H}_{2} \mathrm{O}(\mathrm{am})$ occurs via mass action on mutually accessible surface sites.

\section{Introduction}

Transition metals bind strongly to both iron and manganese oxides $(1-7)$. Sorption to these solids is thought to exert a major control on metal concentrations in surface waters, soils, and groundwaters (8-12). In natural water systems, metallic cations, such as $\mathrm{Cd}, \mathrm{Cu}$, and $\mathrm{Zn}$, do not occur as single solutes but are more often found in combination with other metals and higher concentrations of alkaline-earth cations such as $\mathrm{Ca}^{2+}$ or $\mathrm{Mg}^{2+}$. Therefore, accurate prediction of the extent of metal sorption onto oxides in soil or subsurface materials requires (1) an understanding of the competitive effects between these metal and alkaline-earth cations and (2) descriptive models that can accurately describe the observed presence or absence of competition.

Competitive adsorption between transition-metal cations has been observed on iron and aluminum oxides $(13,14)$ and manganese oxides (15). In binary adsorption experiments with transition metals and cadmium, Benjamin and Leckie $(13,14)$ found that the extent of competition depended on the specific combination of metal cations evaluated (e.g., $\mathrm{Zn}$ had a greater effect on $\mathrm{Cd}$ adsorption than either $\mathrm{Cu}$ or $\mathrm{Pb}$ did). They concluded that each of the metals was predominantly sorbing to different sites and that competition resulted when the metals adsorb to mutually compatible sites. Zasoski and Burau (15), in their evaluation of $\mathrm{Zn}$ and $\mathrm{Cd}$ binary adsorption on $\delta-\mathrm{MnO}_{2}$, also found that their results were best explained by the presence of two types of binding sites with different preferences for the two metals. Swallow et al. (16) were unable to determine whether competition occurred between $\mathrm{Cu}$ and $\mathrm{Pb}$ on amorphous iron oxyhydroxide $\left[\mathrm{Fe}_{2} \mathrm{O}_{3} \cdot \mathrm{H}_{2} \mathrm{O}(\mathrm{am})\right]$ because, for the concentrations evaluated, saturation of the surface was not achieved before the metal hydroxide solid phase formed.
The potential competitive effect of alkaline-earth elements on the sorption of transition metals has received limited attention, yet it may be important in soil solutions, groundwater, and other natural waters in which the dominant electrolyte cation is $\mathrm{Ca}$ or $\mathrm{Mg}$. Dempsey and Singer (17) found that the presence of calcium significantly reduced the sorption of $\mathrm{Zn}$ on $\mathrm{MnO}_{x}$ but not on $\mathrm{Fe}_{2} \mathrm{O}_{3}$. $\mathrm{H}_{2} \mathrm{O}(\mathrm{am})$. In a study of the adsorption of $\mathrm{Cu}, \mathrm{Pb}, \mathrm{Zn}$, and $\mathrm{Cd}$ on goethite in artifical seawater, Balistrieri and Murray (3) determined that sorption of $\mathrm{Mg}$ on the surface of the goethite reduced the sorption of these other metals.

Surface-complexation models [as reviewed in Westall and Hohl (18) and Sposito (9)] have been widely used to describe metal ion sorption on oxide and oxide-like surfaces [for example, Stumm et al. (19), Davis and Leckie (1), and Hayes and Leckie (20)]. These surface-complexation models require knowledge of the properties of the oxide surface and assumptions about the location and form of the sorbed ions in the electrical double layer near the oxide surface. The models have been effective in simulating the sorption of elements from simple solutions; however, their applicability to modeling complex systems where elements in solution may compete with each other for sorption sites has received only limited attention $(3,21-23)$.

The objective of the research described here was to determine whether the sorption of cadmium onto $\mathrm{Fe}_{2} \mathrm{O}_{3} \cdot \mathrm{H}_{2} \mathrm{O}(\mathrm{am})$ is affected by the presence of the alkaline-earth elements $\mathrm{Mg}, \mathrm{Ca}, \mathrm{Sr}$, and $\mathrm{Ba}$ at concentrations representative of soil solutions and groundwaters. Using the sorption data, several alternative surface-complexation modeling approaches for describing the competition between the alkaline-earth elements and $\mathrm{Cd}$ on the $\mathrm{Fe}_{2} \mathrm{O}_{3}$. $\mathrm{H}_{2} \mathrm{O}(\mathrm{am})$ were evaluated.

\section{Experimental Procedures}

All reagents were prepared in distilled, deionized water that was degassed by boiling and then sparging with prepurified $\mathrm{N}_{2}$. The solution $\mathrm{pH}$ was adjusted in the adsorption experiments with $\mathrm{HNO}_{3}$ (Ultrex) and with $\mathrm{CO}_{2}$-free $\mathrm{NaOH}$. The $\mathrm{NaOH}$ was stored under $\mathrm{N}_{2}$ to prevent $\mathrm{CO}_{2}(\mathrm{~g})$ adsorption.

A $10^{-2} \mathrm{M}$ stock solution of $\mathrm{Cd}$ was prepared by dissolving $\mathrm{CdCl}_{2}$ powder (Aldrich Gold Label) in deionized water. A 10 -fold dilution was made to prepare the final $10^{-3} \mathrm{M} \mathrm{Cd}$ stock solution for the adsorption experiments. Carrier-free ${ }^{109} \mathrm{Cd}$ as $\mathrm{CdCl}_{2}$ (New England Nuclear) was used as a radiotracer, and counting was performed by liquid scintillation. The concentration of the $\mathrm{Cd}$ in the stock solution was verified by inductively coupled plasma spectroscopy (ICP). Stock solutions of $7.5 \times 10^{-2} \mathrm{M} \mathrm{Ca}^{2+}, 0.1 \mathrm{M} \mathrm{Mg}^{2+}$, $5 \times 10^{-2} \mathrm{M} \mathrm{Sr}^{2+}$, and $5 \times 10^{-2} \mathrm{M} \mathrm{Ba}^{2+}$ were prepared from their nitrate salts, and their absolute concentrations were confirmed by ICP.

Preparation of Amorphous Iron Oxyhydroxide. Amorphous iron oxyhydroxide $\left[\mathrm{Fe}_{2} \mathrm{O}_{3} \cdot \mathrm{H}_{2} \mathrm{O}(\mathrm{am})\right]$ suspensions were prepared under $\mathrm{N}_{2}$ in water-jacketed, Pyrex flasks as described by Zachara et al. (22). The temperature of the suspension was maintained at $25^{\circ} \mathrm{C}$ by water flowing through the jacket from a refrigerating/heating circulating bath. Carbonate-free conditions were main- 
Table I. Triple-Layer Model Parameters for Amorphous Iron Oxyhydroxide

\begin{tabular}{lll}
\multicolumn{1}{c}{ parameter } & \multicolumn{1}{c}{ value } & ref \\
surface site density $\left(N_{\mathrm{s}}\right)$ & $11 \mathrm{sites} / \mathrm{nm}^{2}$ & 1 \\
surface area $(S)$ & $600 \mathrm{~m}^{2} / \mathrm{g}$ & 24 \\
outer-layer capacitance $\left(C_{2}\right)$ & $0.20 \mathrm{~F} / \mathrm{m}^{2}$ & 1 \\
inner-layer capacitance $\left(\mathrm{C}_{1}\right)$ & $1.25 \mathrm{~F} / \mathrm{m}^{2}$ & 24 \\
\hline
\end{tabular}

tained by using a glovebox with $\mathrm{N}_{2}$ atmosphere or, more commonly, in a reaction flask with continuous $\mathrm{N}_{2}$ sparging to prevent air intrusion. After preparation, the suspension containing $0.043 \mathrm{M} \mathrm{Fe}$ was allowed to equilibrate under $\mathrm{N}_{2}$ atmosphere $\left(25^{\circ} \mathrm{C}\right.$ ) overnight (approximately $14 \mathrm{~h}$ ) before use in the adsorption experiments. An aliquot of the suspension was removed, washed with water several times by centrifugation, and then lyophilized. The lyophilized sample was dissolved in concentrated $\mathrm{HCl}$ (U1trex) and analyzed for $\mathrm{Fe}$. The surface properties of amorphous iron oxide prepared by a similar method have been reported elsewhere $(1,22)$ and are summarized in Table I.

Adsorption Edges. The fractional adsorption of cadmium $\left(10^{-7}\right.$ and $\left.10^{-8} \mathrm{M}\right)$ and calcium $(0.027,0.10,0.20,0.76$, and $2.4 \mathrm{mM}$ ) on $\mathrm{Fe}_{2} \mathrm{O}_{3} \cdot \mathrm{H}_{2} \mathrm{O}(\mathrm{am})$ was determined over a range of $\mathrm{pH}$ in $500-\mathrm{mL}$ jacketed Pyrex flasks. Suspensions of $\mathrm{Fe}_{2} \mathrm{O}_{3} \cdot \mathrm{H}_{2} \mathrm{O}(\mathrm{am})(\sim 0.8 \mathrm{mM} \mathrm{Fe})$ were established in the desired molarity of $\mathrm{NaNO}_{3}(\mathrm{aq})(0.1 \mathrm{M}$ for $\mathrm{Cd}$, and $0.5,0.1$, and $0.005 \mathrm{M}$ for $\mathrm{Ca}$ ). The suspension $\mathrm{pH}$ was adjusted with an automatic $\mathrm{pH}$ stat/titrimeter to the desired starting point between $\mathrm{pH} 4$ and 6 , depending on the sorbate and sorbent concentrations, and the suspension was then equilibrated for $1 \mathrm{~h}$ under $\mathrm{N}_{2}$ with stirring. The appropriate amount of Cd stock solution was then added, yielding approximately $10000 \mathrm{cpm}$ of radiolabel $/ \mathrm{mL}$. Two $10-\mathrm{mL}$ samples of the suspension were removed to $\mathrm{N}_{2}$ purged centrifuge tubes, and the $\mathrm{pH}$ of the suspension was adjusted upward by approximately $0.5 \mathrm{pH}$ unit with the $\mathrm{pH}$ stat/titrimeter. Duplicate samples were removed at each $\mathrm{pH}$, and $\mathrm{pH}$ adjustment continued until the final $\mathrm{pH}$ was attained ( $\mathrm{pH}$ 7-9 depending on the sorbate). The samples in centrifuge tubes were equilibrated with shaking under $\mathrm{N}_{2}$ for $4 \mathrm{~h}$ at $25^{\circ} \mathrm{C}$. Time-course studies indicated that this length of time was adequate for the solutions to achieve steady state. The suspensions were then centrifuged at $4900 \mathrm{rcf}$ at $25^{\circ} \mathrm{C}$, and the final $\mathrm{pH}$ was measured with a Ross combination electrode under $\mathrm{N}_{2}$. Subsamples of the supernatant were placed in tared, acidified (with Ultrex $\mathrm{HCl}$ ) vials for scintillation counting (glass vials) and ICP analysis (plastic vials).
For the competition experiments involving cadmium with each of the alkaline-earth elements, the $\mathrm{Fe}_{2} \mathrm{O}_{3} \cdot \mathrm{H}_{2} \mathrm{O}$ (am) suspension described above was spiked with the appropriate amount of alkaline-earth $(\mathrm{Ca}, \mathrm{Mg}, \mathrm{Ba}$, or $\mathrm{Sr})$ stock solution and equilibrated for $1 \mathrm{~h}$. A $10-\mathrm{mL}$ subsample of the solution was removed and centrifuged at $4900 \mathrm{rcf}$ for $20 \mathrm{~min}$. The supernatant was then removed for ICP analysis of the alkaline-earth concentration. Appropriate amounts of electrolyte and Cd stock solutions were added and the experiments continued as described in the preceding paragraph. Competition was evaluated with $\mathrm{Cd}$ at $10^{-6} \mathrm{M}$ and the alkaline-earth cations at various concentrations summarized in Table II. Care was taken in all the experiments to exclude $\mathrm{CO}_{2}(\mathrm{~g})$ ), which would otherwise cause the precipitation of the alkaline-earth carbonates. The $\mathrm{M}^{2+}$ concentrations were below the concentration at which either hydroxide or carbonate solids would form if the solutions were in equilibrium with atmospheric $\mathrm{CO}_{2}(\mathrm{~g})$

Desorption. To determine the effect of addition of various $\mathrm{Ca}$ concentrations on the desorption of $\mathrm{Cd}$ from $\mathrm{Fe}_{2} \mathrm{O}_{3} \cdot \mathrm{H}_{2} \mathrm{O}(\mathrm{am})$, Cd was sorbed onto $\mathrm{Fe}_{2} \mathrm{O}_{3} \cdot \mathrm{H}_{2} \mathrm{O}(\mathrm{am})$ by the method described for the adsorption edges. After the $\mathrm{Cd}$ had equilibrated with the $\mathrm{Fe}_{2} \mathrm{O}_{3} \cdot \mathrm{H}_{2} \mathrm{O}(\mathrm{am})$ for $4 \mathrm{~h}$, subsamples were removed for analysis to determine the adsorbed concentration. Calcium was added at concentrations of $0.25,2.5$, and $25 \mathrm{mM}$. Samples and $\mathrm{pH}$ measurements at each $\mathrm{Ca}$ concentration were taken after 24 , 48 , and $144 \mathrm{~h}$. The samples were analyzed for $\mathrm{Cd}$ by scintillation counting, and $\mathrm{Ca}$ was measured by ICP.

Adsorption Modeling. Adsorption constants for the triple-layer model (TLM) representing the sorption of $\mathrm{Cd}$ and $\mathrm{Ca}$ individually on $\mathrm{Fe}_{2} \mathrm{O}_{3} \cdot \mathrm{H}_{2} \mathrm{O}(\mathrm{am})$ were determined by using the program FITEQL $(25,26)$ and the surface characteristics of $\mathrm{Fe}_{2} \mathrm{O}_{3} \cdot \mathrm{H}_{2} \mathrm{O}(\mathrm{am})$ given in Tables I and III. Solution-complexation reactions and associated constants for $\mathrm{Cd}$ and the alkaline-earth elements are also given in Table III.

Adsorption constants for a nonelectrostatic site-binding model (NEM) for the sorption of $\mathrm{Cd}$ and $\mathrm{Ca}$ individually on $\mathrm{Fe}_{2} \mathrm{O}_{3} \cdot \mathrm{H}_{2} \mathrm{O}(\mathrm{am})$ were also determined with the program FITEQL. This model treats the binding of metal ions to oxide surfaces as analogous to complexation with ligands in solution. The surface area and site densities given in Table I were used to represent the $\mathrm{Fe}_{2} \mathrm{O}_{3} \cdot \mathrm{H}_{2} \mathrm{O}(\mathrm{am})$; the capacitances were not needed because this model contains no electrostatic terms. The acidity and electrolyte constants were determined by fitting them to potentiometric titration data (27) with FITEQL (Table III). The NEM fit to the potentiometric titration data was not quite as good

Table II. Experimental Conditions for Competition Experiments

\begin{tabular}{lll} 
& \multicolumn{2}{c}{ alkaline earth } \\
\cline { 2 - 3 } ref & element & concn, M \\
$b$ & $\mathrm{Mg}$ & $7.5 \times 10^{-3}$ \\
$b$ & $\mathrm{Ca}$ & $2.5 \times 10^{-3}$ \\
$b$ & $\mathrm{Ca}$ & $7.5 \times 10^{-3}$ \\
$b$ & $\mathrm{Ca}$ & $2.5 \times 10^{-3}$ \\
$b$ & $\mathrm{Ca}$ & $2.5 \times 10^{-3}$ \\
$b$ & $\mathrm{Ca}$ & $2.5 \times 10^{-3}$ \\
$b$ & $\mathrm{Sr}$ & $5.1 \times 10^{-4}$ \\
$b$ & $\mathrm{Ba}$ & $5.0 \times 10^{-4}$ \\
$b$ & $\mathrm{Ba}$ & $1.0 \times 10^{-3}$ \\
$b$ & $\mathrm{Sr}$ & $5 \times 10^{-4}$ \\
$b$ & $\mathrm{Ba}$ & $1 \times 10^{-3}$ \\
3 & $\mathrm{Mg}$ & 0.054 \\
3 & $\mathrm{Mg}$ & 0.054 \\
17 & $\mathrm{Ca}$ & $1 \times 10^{-3}$
\end{tabular}

\begin{tabular}{cc}
\multicolumn{2}{c}{ transition metal } \\
\hline element & \multicolumn{1}{c}{ concn, M } \\
$\mathrm{Cd}$ & $1 \times 10^{-6}$ \\
$\mathrm{Cd}$ & $1 \times 10^{-6}$ \\
$\mathrm{Cd}$ & $1 . \times 10^{-6}$ \\
$\mathrm{Cd}$ & $1 \times 10^{-6}$ \\
$\mathrm{Cd}$ & $1 \times 10^{-6}$ \\
$\mathrm{Cd}$ & $1 \times 10^{-6}$ \\
$\mathrm{Cd}$ & $8.9 \times 10^{-7}$ \\
$\mathrm{Cd}$ & $8.9 \times 10^{-7}$ \\
$\mathrm{Cd}$ & $8.9 \times 10^{-7}$ \\
$\mathrm{Cd}$ & $8.9 \times 10^{-7}$ \\
$\mathrm{Cd}$ & $8.9 \times 10^{-7}$ \\
$\mathrm{Zn}$ & $2.7 \times 10^{-6}$ \\
$\mathrm{Cd}$ & $2.8 \times 10^{-6}$ \\
$\mathrm{Zn}$ & $3 \times 10^{-6}-7.6 \times 10^{-7}$
\end{tabular}

ionic strength, $\mathrm{M}$

$0.1 \mathrm{NaNO}_{3}$

$0.1 \mathrm{NaNO}_{3}$

$0.1 \mathrm{NaNO}_{3}$

$0.1 \mathrm{NaNO}_{3}$

$0.5 \mathrm{NaNO}_{3}$

$0.005 \mathrm{NaNO}$

$0.1 \mathrm{NaNO}_{3}$

$0.1 \mathrm{NaNO}_{3}$

$0.1 \mathrm{NaNO}_{3}$

$0.1 \mathrm{NaNO}_{3}$

$0.1 \mathrm{NaNO}_{3}$

$0.53 \mathrm{NaCl}+0.054 \mathrm{MgCl}_{2}$

$0.53 \mathrm{NaCL}+0.054 \mathrm{MgCl}_{2}$

$0.01 \mathrm{NaNO}_{3}$

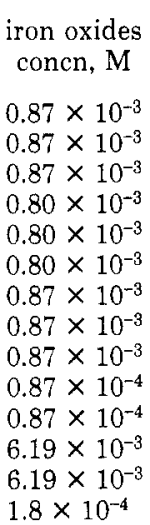

$\mathrm{pH}$

$50 \%^{a} \quad$ iron oxide

$7.0 \mathrm{Fe}(\mathrm{OH})(\mathrm{am})$

$7.3 \mathrm{Fe}(\mathrm{OH})(\mathrm{am})$

$7.3 \mathrm{Fe}(\mathrm{OH})(\mathrm{am})$

$7.0 \quad \mathrm{Fe}(\mathrm{OH})(\mathrm{am})$

$6.9 \quad \mathrm{Fe}(\mathrm{OH})(\mathrm{am})$

$6.9 \mathrm{Fe}(\mathrm{OH})(\mathrm{am})$

$6.7 \quad \mathrm{Fe}(\mathrm{OH})(\mathrm{am})$

$6.7 \mathrm{Fe}(\mathrm{OH})(\mathrm{am})$

$6.7 \mathrm{Fe}(\mathrm{OH})(\mathrm{am})$

$6.7 \mathrm{Fe}(\mathrm{OH})(\mathrm{am})$

$6.7 \mathrm{Fe}(\mathrm{OH})(\mathrm{am})$

$\gamma-\mathrm{FeOOH}$

$\gamma$ - $\mathrm{FeOOH}$

$\mathrm{Fe}(\mathrm{OH})_{3}(\mathrm{am})$

${ }^{a}$ For $\mathrm{Cd}$ alone $\mathrm{pH}_{50 \%}=6.7 .{ }^{b}$ This study 
Table III. Surface Acid/Base and Electrolyte Sorption Reactions and Aqueous Speciation Reactions with Associated Equilibrium Constants

\begin{tabular}{|c|c|c|}
\hline \multirow[b]{2}{*}{ reaction } & \multicolumn{2}{|c|}{$\log K_{\mathrm{r}}$} \\
\hline & TLM & NEM \\
\hline 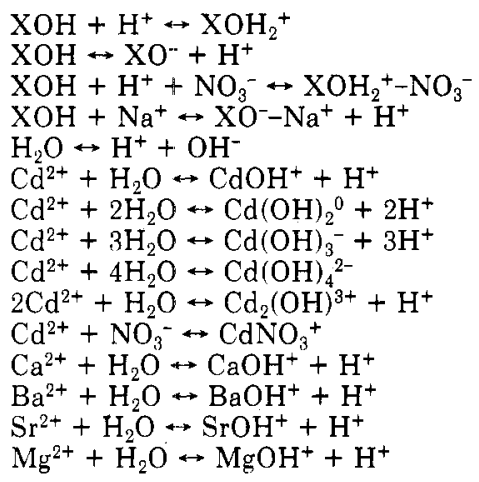 & $\begin{array}{r}5.4^{a} \\
-10.4^{a} \\
7.5^{a} \\
-8.3^{a} \\
-14.0^{c} \\
-10.08^{c} \\
-20.35^{c} \\
-33.30^{c} \\
-47.35^{c} \\
-9.39^{c} \\
0.399^{c} \\
-12.60^{c} \\
-13.36^{c} \\
-13.18^{c} \\
-11.79^{c}\end{array}$ & $\begin{array}{c}4.7^{b} \\
-10.3^{b} \\
6.3^{b} \\
-9.1^{b} \\
-14.0^{c} \\
=10.08^{c} \\
-20.35^{c} \\
-33.30^{c} \\
-47.35^{c} \\
-9.39^{c} \\
0.399^{c} \\
-12.60^{c}\end{array}$ \\
\hline
\end{tabular}

${ }^{a}$ Davis and Leckie (1). ${ }^{b}$ Fit to potentiometric titration data in Davis (27). ' Ball et al. (28).

as that of the TLM. The solution reactions and associated complexation constants used in this model are also given in Table III. This model has been discussed in greater detail by Krupka et al. (29).

The standard deviations for the adsorption constants were estimated by FITEQL by assuming $1 \%$ relative and $5 \%$ absolute error in the experimental data.

\section{Results and Discussion}

Single-Element Adsorption. Cadmium. The fractional adsorption of $\mathrm{Cd}\left(10^{-6}\right.$ and $\left.10^{-7} \mathrm{M}\right)$ increased from 0 to $100 \%$ over the $\mathrm{pH}$ range from 5 to 8.5 (Figure 1) and was identical with that noted by other investigators (13, $14,30,31)$. The $\mathrm{pH}$ of $50 \%$ adsorption was 6.4 for $10^{-7}$ $\mathrm{M} \mathrm{Cd}$ and 6.7 for $10^{-6} \mathrm{M} \mathrm{Cd}$. As is typical of cation adsorption, the $\mathrm{pH}$ of $50 \%$ adsorption increased as the concentration of the cadmium and thus the ratio of adsorbate (Cd) to adsorbent $\left[\mathrm{Fe}_{2} \mathrm{O}_{3} \cdot \mathrm{H}_{2} \mathrm{O}(\mathrm{am})\right]$ increased (13, 14).

Individual Alkaline-Earth Elements. Because $\mathrm{Ca}^{2+}$ is a dominent electrolyte ion in soil solutions and groundwater, its adsorption behavior on $\mathrm{Fe}_{2} \mathrm{O}_{3} \cdot \mathrm{H}_{2} \mathrm{O}(\mathrm{am})$ was investigated over ranges of concentration and electrolyte ion concentration (Figure 2) representative of typical environmental conditions. The adsorption of $\mathrm{Ca}$, like that of $\mathrm{Cd}$, increased with $\mathrm{pH}$, consistent with the observations of other researchers $(17,32,33)$. The effect of $\mathrm{pH}$ was most marked for the lowest $\mathrm{Ca}$ concentrations (curve a in Figure 2). The adsorption of $\mathrm{Ca}$ was shifted to a higher $\mathrm{pH}$ than that of $\mathrm{Cd}$, which was a result of both the higher concentration of $\mathrm{Ca}$ (and therefore higher adsorbate-to-adsorbent ratio) and its lower affinity for the surface. With constant initial $\mathrm{Ca}$ concentration, increasing the ionic strength through $\mathrm{NaNO}_{3}$ addition decreased $\mathrm{Ca}$ adsorption (curves b, d, and e in Figure 2).

The decrease in $\mathrm{Ca}$ adsorption with increasing initial solution concentration could have been caused by a shortage of ionized sites available to complex with the $\mathrm{Ca}$. As illustrated in Table IV, the amount of $\mathrm{Ca}$ sorbed on the surface of the $\mathrm{Fe}_{2} \mathrm{O}_{3} \cdot \mathrm{H}_{2} \mathrm{O}(\mathrm{am})$ at $\mathrm{pH} 10$ increased less than 1 order of magnitude when the initial concentration of $\mathrm{Ca}$ increased almost 2 orders of nagnitude or the ionic strength increased 2 orders of magnitude. As the concentration of $\mathrm{Ca}$ in solution increased relative to the $\mathrm{Fe}_{2} \mathrm{O}_{3} \cdot \mathrm{H}_{2} \mathrm{O}(\mathrm{am})$ concentration (i.e., $\mathrm{Ca} / \mathrm{Fe}$ molar ratio increased), the calculated percentages of the ionized and total sites oc-
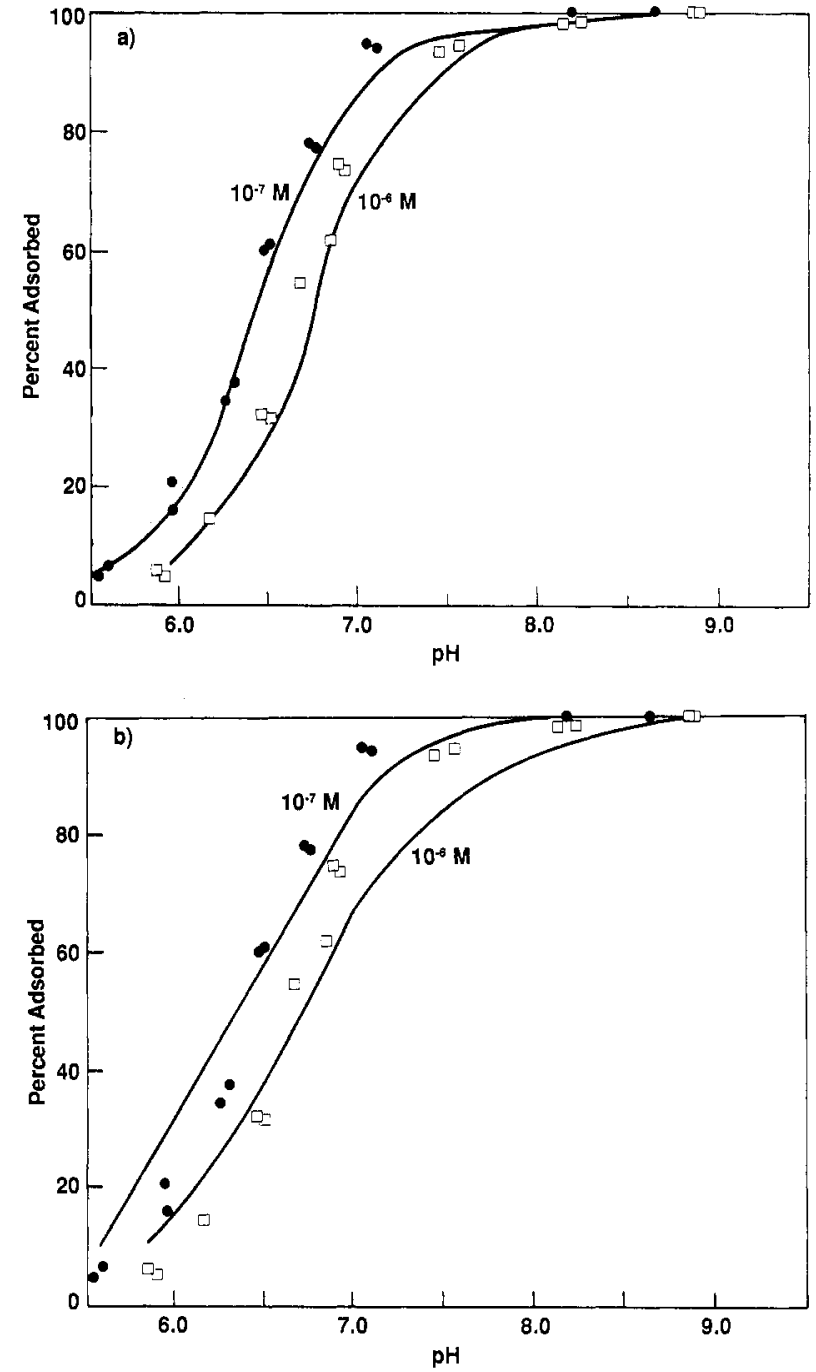

Figure 1. Adsorption of $10^{-7}$ and $10^{-6} \mathrm{M} \mathrm{Cd}$ onto amorphous iron oxyhydroxide $(0.87 \mathrm{mM} \mathrm{Fe})$ at $I=0.1 \mathrm{M}$. (a) Experimental data and predicted sorption using inner-sphere representation of sorption reaction and triple-layer model. (b) Experimental data and predicted sorption using nonelectrostatic model representation of sorption reaction.

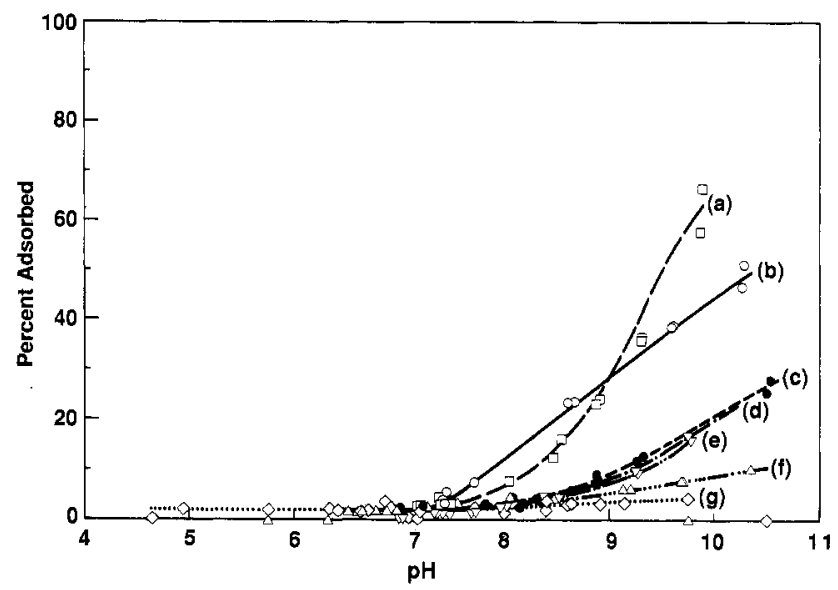

Figure 2. Adsorption of $\mathrm{Ca}$ onto amorphous iron oxyhydroxide. (a) $[\mathrm{Ca}]=0.027 \mathrm{mM}, I=0.1 \mathrm{M}, 0.79 \mathrm{mM} \mathrm{Fe}$. (b) $[\mathrm{Ca}]=0.1 \mathrm{mM}, I$ $=0.005 \mathrm{M}, 0.77 \mathrm{mM} \mathrm{Fe}$. (c) $[\mathrm{Ca}]=0.202 \mathrm{mM}, I=0.1 \mathrm{M}, 0.79 \mathrm{mM}$ $\mathrm{Fe}$. (d) $[\mathrm{Ca}]=0.1 \mathrm{mM}, I=0.1 \mathrm{M}, 0.78 \mathrm{mM} \mathrm{Fe}$. (e) $[\mathrm{Ca}]=0.1 \mathrm{mM}$, $I=0.5 \mathrm{M}, 0.78 \mathrm{mM} \mathrm{Fe}$. (f) $[\mathrm{Ca}]=0.764 \mathrm{mM}, I=0.1 \mathrm{M}, 0.87 \mathrm{mM}$ Fe. (g) $[\mathrm{Ca}]=2.4 \mathrm{mM}, I=0.1 \mathrm{M}, 0.81 \mathrm{mM}$ Fe.

cupied by sorbed $\mathrm{Ca}$ increased. However, the increase in percentage of sites occupied was not proportional to the increase in $\mathrm{Ca}$ concentration. 
Table IV. Experimental Conditions for Calcium Adsorption onto Amorphous Iron Oxyhydroxide

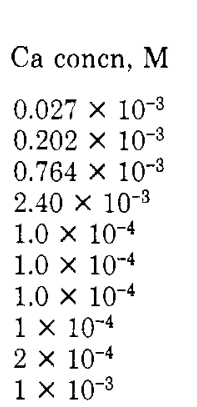

ionic strength
$\mathrm{M} \mathrm{NaNO}_{3}$

0.1
0.1
0.1
0.1
0.005
0.1
0.5
0.01
0.01
1
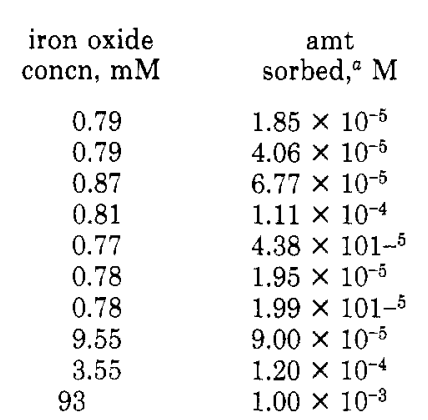

total
surface sites
occupied, \%

3.8
8.4
12.5
22.4
9.3
4.1
4.2
4.1
5.5
1.8

ionized

sites occupied, ${ }^{b} \quad$ ref

$\begin{array}{ll}40 & c \\ 66 & c \\ 66 & c \\ 71 & c \\ 80 & c \\ 41 & c \\ 23 & c \\ & 17 \\ & 17 \\ & 33\end{array}$

${ }^{a}$ Amount sorbed at $\mathrm{pH} 10 .{ }^{b}$ Total ionized sites calculated as the sum of $\mathrm{XO}^{-}, \mathrm{XO}^{-}-\mathrm{Na}^{+}$, and sites occupied by adsorbed Ca. ${ }^{c}$ This study.
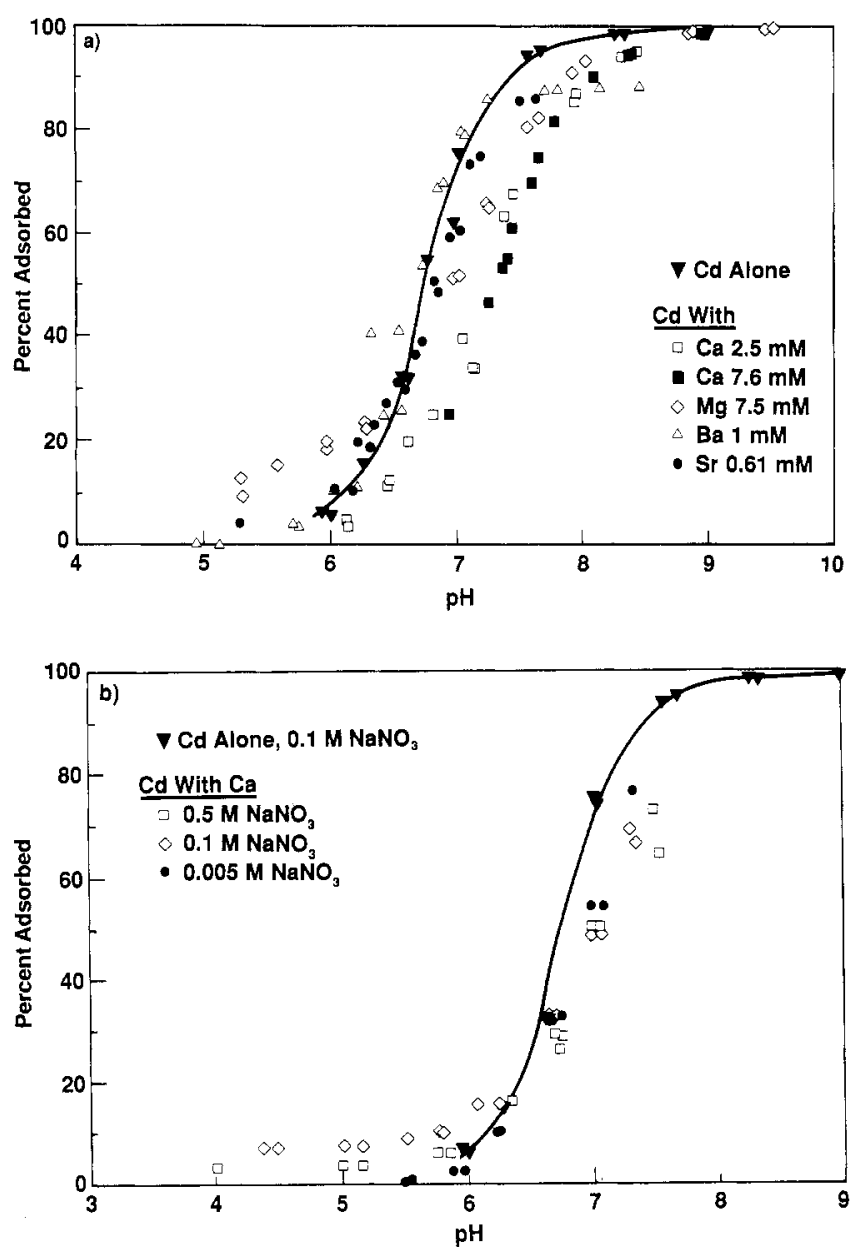

Figure 3. Adsorption of $\left(10^{-6} \mathrm{M}\right) \mathrm{Cd}$ on amorphous iron oxyhydroxide in the presence of alkaline-earth elements. (a) For elements at concentrations given with $0.87 \mathrm{mM} \mathrm{Fe}$ in $0.1 \mathrm{M} \mathrm{NaNO}_{3}$. (b) For $2.5 \mathrm{mM}$ $\mathrm{Ca}$ with $0.80 \mathrm{mM} \mathrm{Fe}$ at ionic strengths given.

Binary-Element Adsorption. The binary-element adsorption edges show $\mathrm{Cd}$ competition with $\mathrm{Ca}$ and, to a lesser extent, with $\mathrm{Mg}$ (Figure $3 \mathrm{a}$ ). The concentrations of alkaline-earth elements were chosen to be less than the concentration at which either hydroxide or carbonate solids could form; thus, the solution concentrations of $\mathrm{Sr}$ and $\mathrm{Ba}$ were limited to values lower than could be used for $\mathrm{Ca}$ or $\mathrm{Mg}$. Increasing the ionic strength (by means of $\mathrm{NaNO}_{3}$ addition) over 2 orders of magnitude at constant $\mathrm{Ca}(2.5$ $\mathrm{mM})$ and $\mathrm{Cd}\left(10^{-6} \mathrm{M}\right)$ concentrations had minimal effect on the competition (Figure $3 \mathrm{~b}$ ), especially over the $\mathrm{pH}$ range $6-7.5$. This finding parallels the observation that, in the absence of $\mathrm{Ca}, \mathrm{Cd}$ adsorption is insensitive to ionic strength ( $\mathrm{Na}$ concentration) (20). The $\mathrm{pH}$ of $50 \%$ ad-

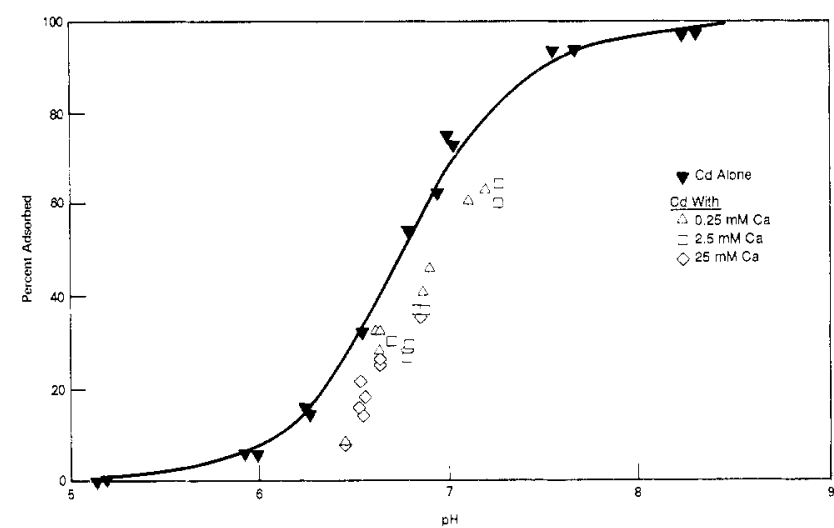

Figure 4. Desorption of adsorbed $\left(10^{-6} \mathrm{M}\right) \mathrm{Cd}$ from amorphous iron oxyhydroxide $(0.87 \mathrm{mM} \mathrm{Fe})$ by $\mathrm{Ca}$ addition at concentrations given in $0.1 \mathrm{M} \mathrm{NaNO}_{3}$

sorption for each of these experiments, along with published data from other similar binary-element adsorption studies on iron oxides, are given in Table II.

The addition of $\mathrm{Ca}$ (at $0.25,2.5$, and $25 \mathrm{mM}$ ) was found to desorb $\mathrm{Cd}$ from $\mathrm{Fe}_{2} \mathrm{O}_{3} \cdot \mathrm{H}_{2} \mathrm{O}(\mathrm{am})$ (Figure 4). The addition of $\mathrm{Ca}$ at all concentrations resulted in decreased adsorption of $\mathrm{Cd}$, as was observed for the $\mathrm{Cd}-\mathrm{Ca}$ competition experiments where the $\mathrm{Fe}_{2} \mathrm{O}_{3} \cdot \mathrm{H}_{2} \mathrm{O}(\mathrm{am})$ was loaded with the Ca first (Figure 3a,b). Desorption data at 4, 24, 48 , and $144 \mathrm{~h}$ (not shown) indicated that equilibrium was achieved rapidly, given that the fractional $\mathrm{Cd}$ adsorption after $24 \mathrm{~h}$ in the desorption experiment with $2.5 \mathrm{mM} \mathrm{Ca}$ was equal to that in the sorption experiment in which $\mathrm{Ca}$ was added first. Thus, it appears that the competitive effects were not dependent on the order of loading and were reversible. These results also showed that, above a certain $\mathrm{Ca}$ concentration, addition of $\mathrm{Ca}$ did not result in further desorption because $\mathrm{Cd}$ adsorption in the presence of 2.5 and $25 \mathrm{mM}$ of $\mathrm{Ca}$ was equal.

Overall, these results suggest that competition between $\mathrm{Cd}$ and $\mathrm{Ca}$ is limited to a fixed portion of mutually accessible surface sites. We observed competition when $\mathrm{Ca}$ occupied $66 \%$ or more of the ionized sites and more than $8 \%$ of the total surface sites (Table II). Competition decreased as the $\mathrm{Ca}$ concentration and the site coverage by $\mathrm{Ca}$ decreased. These conclusions based on coverage of ionized sites are consistent with Dzombak's finding (34) that competitive effects are only important when full site coverage is approached. The lack of competition between $\mathrm{Cd}$ and $\mathrm{Ba}$ or $\mathrm{Sr}$ could not be accounted for by differences in site coverage, because even at site coverages where competition between $\mathrm{Cd}$ and $\mathrm{Ca}$ was observed, no competition with $\mathrm{Ba}$ and $\mathrm{Sr}$ was observed. Thus, site coverage alone did not explain the presence or absence of competitive sorption between $\mathrm{Cd}$ and the different alkaline-earth 
elements. The lack of effect of $\mathrm{Sr}$ and $\mathrm{Ba}$ on $\mathrm{Cd}$ adsorption is probably due to these two elements being less strongly sorbed to amorphous iron oxyhydroxide than $\mathrm{Ca}$.

Absorption Modeling. Several surface-complexation models have been used to describe sorption phenomena in a variety of environmental contexts $(3,35-37)$. These surface-complexation models differ in the number of planes within the solid-liquid interface in which ion adsorption is assumed to occur, and in how and to what extent electrostatics are propagated through this interface (i.e., double layer). These models include (1) the triple-layer model (1, $20)$, (2) the constant-capacitance model $(19,38),(3)$ the diffuse-layer model (34), and (4) the nonelectrostatic model $(19,29)$. Many of these models have been shown to provide equivalent representations of metal ion adsorption on oxides (18), but their ability to accurately describe competitive sorption phenomena in natural waters has not been addressed. For this reason, the most complex (TLM) and the least complex (NEM) of the site-binding models, where "complex" is used to indicate the number of adjustable parameters, were evaluated for their ability to describe the binary $\mathrm{Ca}-\mathrm{Cd}$ sorption data.

The surface complexes used in the subsequent analyses are hypothetical and were chosen for their ability to represent the adsorption data. The conclusion that surface complexes similar to those used in the present modeling analyses do form has been supported by spectroscopy $(9$, 39). However, the fact that the different surface complexes can represent the adsorption data is not proof that these complexes actually exist on the sorbate surface.

Cadmium Adsorption. The $\mathrm{Cd}$ data were modeled in two ways by use of the TLM. In the first, $\mathrm{Cd}$ was assumed to form only inner-sphere complexes (i.e., complexes in the o-plane). The inner-sphere surface complex represents a close approach to the surface by the element and a strong chemical interaction between the element and the surface, and this behavior is one possible explanation for the observation that $\mathrm{Cd}$ sorption is insensitive to the ionic strength of the supporting electrolyte solution (20). The formation of such complexes has been hypothesized for strongly adsorbed cations, such as $\mathrm{Cu}, \mathrm{Pb}, \mathrm{Ni}$, and $\mathrm{Cd}(20)$. The inner-sphere surface complexation reaction was represented by

$$
\mathrm{Cd}^{2+}+\mathrm{XOH} \leftrightarrow \mathrm{XOCd}^{+}+\mathrm{H}^{+}
$$

where $\mathrm{XOH}$ represents a surface site. The fitted $\log K$ value for this reaction was $-1.9 \pm 0.05$ for $10^{-6} \mathrm{M} \mathrm{Cd}$ and $-1.4 \pm 0.04$ for $10^{-7} \mathrm{M} \mathrm{Cd}$. Only the single inner-sphere surface complex with $\mathrm{Cd}$ was required to represent the data for $\mathrm{Cd}$ adsorption on $\mathrm{Fe}_{2} \mathrm{O}_{3} \cdot \mathrm{H}_{2} \mathrm{O}(\mathrm{am})$ at $I=0.1 \mathrm{M}$ (Figure 1a). Hayes and Leckie (20) also found that only this single complex was required to model the adsorption of $\mathrm{Cd}$ and $\mathrm{Pb}$ on goethite.

In the second TLM modeling approach, Cd was assumed to form only outer-sphere complexes (i.e., complexes in the $\beta$-plane). This approach was consistent with past modeling of metal ion adsorption $(1,5,13,14,30)$. The surfacecomplexation reactions were represented by

$$
\mathrm{Cd}^{2+}+\mathrm{XOH} \leftrightarrow \mathrm{XO}^{-}-\mathrm{Cd}^{2+}+\mathrm{H}^{+}
$$

and

$$
\mathrm{Cd}^{2+}+\mathrm{XOH}+\mathrm{H}_{2} \mathrm{O} \leftrightarrow \mathrm{XO}^{-}-\mathrm{CdOH}^{+}+2 \mathrm{H}^{+}
$$

The fitted sorption constants were $-9.3 \pm 0.04$ and -10.7 \pm 0.04 for the two reactions for $10^{-6} \mathrm{M} \mathrm{Cd}$ at $I=0.1 \mathrm{M}$ and $-9.3 \pm 0.04$ and $-10.4 \pm 0.04$ for the two reactions for $10^{-7} \mathrm{M} \mathrm{Cd}$ at $I=0.1 \mathrm{M}$. It was necessary to include surface species containing both $\mathrm{Cd}^{2+}$ and $\mathrm{CdOH}^{+}$to describe the sorption of $\mathrm{Cd}$ when outer-sphere surface complexes were assumed. The fit to the data was slightly better for the inner-sphere surface complex than for the outer-sphere surface complexes.

For the NEM, cadmium was assumed to form only one surface complex. The surface complexation reaction was

$$
\mathrm{Cd}^{2+}+\mathrm{XOH} \leftrightarrow \mathrm{XOCd}^{+}+\mathrm{H}^{+}
$$

The fitted sorption constants were $-3.1 \pm 0.04$ and -2.8 \pm 0.04 for $10^{-6}$ and $10^{-7} \mathrm{M} \mathrm{Cd}$, respectively, at $I=0.1 \mathrm{M}$. The NEM fit to the Cd adsorption edge data was not quite as good as that of the TLM. The Cd adsorption edge calculated by the NEM was flatter (rose less steeply) than the measured adsorption edge (Figure 1b). The applicability of the NEM to a larger range in $\mathrm{Cd}^{2+}$ and $\mathrm{Fe}_{2} \mathrm{O}_{3}$. $\mathrm{H}_{2} \mathrm{O}(\mathrm{am})$ concentrations was shown by Krupka et al. (29).

For all three representations, the adsorption constants for the two initial $\mathrm{Cd}$ concentrations at $I=0.1 \mathrm{M}$ were statistically different. The $10^{-7} \mathrm{M} \mathrm{Cd}$ constants indicate greater affinity of the $\mathrm{Cd}$ for the surface than do the $10^{-6}$ $\mathrm{M}$ Cd constants. This observation is consistent with what would be expected with a heterogeneous surface where the average site energy, and thus the average sorption constant, decreases with increasing site coverage.

Calcium Adsorption. Several types of surface-complexation reactions were evaluated by using both the TLM and the NEM for describing the calcium adsorption data. The TLM reactions included various outer-sphere complexes and a combination of both inner- and outer-sphere complexes. The combination of inner- and outer-sphere complexes was found to be necessary to model the binary $\mathrm{Cd}-\mathrm{Ca}$ experiments.

Most of the surface complexes evaluated for $\mathrm{Ca}$ were outer-sphere surface complexes consistent with most past modeling. Outer-sphere complex formation represents a weak complex with the surface and may account for the sensitivity of $\mathrm{Ca}$ and other alkaline-earth element sorption to ionic strength (Figure 2; refs 20, 32, and 40). The outer-sphere surface complexation reactions evaluated included (1) complexes with $\mathrm{Ca}^{2+}$ and $\mathrm{CaOH}^{+}$, both individually and together, and (2) the bidentate complex with $\mathrm{Ca}^{2+}$, both individually and together with $\mathrm{CaOH}^{+}$. Dempsey and Singer (17) and Balistrieri and Murray (41) used the bidentate complex to represent the sorption of alkaline-earth elements on $\mathrm{Fe}_{2} \mathrm{O}_{3} \cdot \mathrm{H}_{2} \mathrm{O}(\mathrm{am})$ and goethite, respectively. In this study, the two outer-sphere surface complexation reactions that best represented the data for the TLM were the bidentate complex with $\mathrm{Ca}^{2+}$

$$
\mathrm{Ca}^{2+}+2 \mathrm{XOH} \leftrightarrow\left(\mathrm{XO}^{-}\right)_{2}-\mathrm{Ca}^{2+}+2 \mathrm{H}^{+}
$$

and the complex with $\mathrm{CaOH}^{+}$

$$
\mathrm{Ca}^{2+}+\mathrm{XOH}+\mathrm{H}_{2} \mathrm{O} \rightarrow \mathrm{XO}^{-}-\mathrm{CaOH}^{+}+2 \mathrm{H}^{+}
$$

The fitted constants for these two reactions are given in columns 6 and 7 of Table V. For comparison, the fitted constants for the outer-sphere complexes with $\mathrm{Ca}^{2+}$ and $\mathrm{CaOH}^{+}$are given in columns 4 and 5 of Table V. Our constants for the outer-sphere complexes with $\mathrm{Ca}^{2+}$ and $\mathrm{CaOH}^{+}$were very similar to those determined by Balistrieri and Murray (3) for Ca in seawater ( $\log * K$ is -5.0 for $\mathrm{Ca}^{2+}$ and -14.5 for $\mathrm{CaOH}^{+}$at $I=\sim 0.7 \mathrm{M}$ ).

To accurately model the observed competition between $\mathrm{Ca}$ and $\mathrm{Cd}, \mathrm{Ca}$ was hypothesized to form a combination of inner- and outer-sphere complexes. The inner- and outer-sphere complexes that best represented the singleelement sorption data were

$$
\mathrm{Ca}^{2+}+2 \mathrm{XOH} \leftrightarrow\left(\mathrm{XO}^{-}\right)_{2}-\mathrm{Ca}^{2+}+2 \mathrm{H}^{+}
$$

for the outer-sphere complex and

$$
\mathrm{Ca}^{2+}+\mathrm{XOH} \leftrightarrow \mathrm{XOCa}^{+}+\mathrm{H}^{+}
$$


triple-layer model

\begin{tabular}{|c|c|c|c|c|c|c|c|c|c|}
\hline \multirow[b]{3}{*}{$\mathrm{Ca}, \mathrm{mM}$} & \multirow[b]{3}{*}{$\mathrm{Fe}, \mathrm{mM}$} & \multirow{3}{*}{$\begin{array}{c}\text { ionic } \\
\text { strength, } \\
\mathrm{M} \mathrm{NaNO}\end{array}$} & & \multirow[b]{3}{*}{$\begin{array}{l}\mathrm{NEM}^{e} \\
\log K^{d}\end{array}$} \\
\hline & & & \multicolumn{2}{|c|}{ outer sphere } & \multicolumn{2}{|c|}{ outer sphere } & \multicolumn{2}{|c|}{ inner and outer sphere } & \\
\hline & & & $\begin{array}{c}\log * K \\
\mathrm{XO}-\mathrm{Ca}^{2+a}\end{array}$ & $\begin{array}{c}\log * K \\
\mathrm{XO}-\mathrm{CaOH}{ }^{+b}\end{array}$ & $\begin{array}{c}\log * K \\
\mathrm{XO}-\mathrm{CaOH}^{+b}\end{array}$ & $\begin{array}{c}\log * \bar{K} \\
\text { bidentate }\end{array}$ & $\begin{array}{l}\log * K \\
\text { outer }\end{array}$ & $\begin{array}{l}\log * K \\
\text { inner }\end{array}$ & \\
\hline 2.4 & 0.81 & 0 & \pm 1.5 & $-14.3 \pm 1.7$ & $14,2+1,1$ & +1.0 & $-7.55 \pm 1.3$ & -1.011 & .49 \\
\hline 0.764 & 0.87 & & $-4.45 \pm 0.65$ & $-15.3 \pm 0.37$ & $-15.3 \pm 0.37$ & -10.0 & $-10.0 \pm 0.45$ & $-8.36 \pm$ & -6.8 \\
\hline 0.202 & 0.79 & 0.1 & $-4.43 \pm 0.37$ & $-14.9 \pm 0.19$ & $-14.9 \pm 0.1$ & $-9.62 \pm 0.26$ & $-9.60 \pm 0.25$ & $-8.48 \pm$ & -6.4 \\
\hline 0.027 & 0.79 & 0. & $-5.03 \pm 0.21$ & $-14.0 \pm 0.08$ & $-14.0 \pm 0.09$ & -9.74 & $-9.66 \pm$ & $-6.97 \pm 0$ & .04 \\
\hline 0.1 & 0.77 & 0. & $-5.43 \pm 0.59$ & $-14.5 \pm 0.15$ & $-14.5 \pm 0.16$ & $-10.1 \pm 0.40$ & $-10.0 \pm 0.37$ & $-7.36 \pm 0.34$ & -6 \\
\hline 0.1 & 0.78 & & $-4.92 \pm 0.35$ & $-15.4 \pm 0.15$ & $-15.4 \pm 0.20$ & $-9.86 \pm 0.23$ & $-9.85 \pm 0.23$ & $-9.21 \pm 0.46$ & -6.5 \\
\hline 0.1 & 0.78 & 0.005 & \pm 0.47 & $-14.1 \pm 0.15$ & $-14.1 \pm 0$ & $-8.38 \pm 0.34$ & -8.2 & $-8.17 \pm 0.23$ & $-6.30 \pm 0.05$ \\
\hline combi & $0.1 \mathrm{IIN}$ & $1 \mathrm{Ca}$ data & $-4.87 \pm 0.22$ & $-15.0 \pm 0.09$ & $-15.0 \pm 0.09$ & $-9.77 \pm 0.14$ & $-9.72 \pm 0.13$ & $-8.46 \pm 0.17$ & $-6.38 \pm 0.04$ \\
\hline
\end{tabular}

${ }^{a} \mathrm{Ca}^{2+}+\mathrm{XOH} \rightarrow \mathrm{XO}^{-}-\mathrm{Ca}^{2+}+\mathrm{H}^{+} .{ }^{b} \mathrm{Ca}^{2+}+\mathrm{H}_{2} \mathrm{O}+\mathrm{XOH} \leftrightarrow \mathrm{XO}^{-}-\mathrm{CaOH}^{+}+2 \mathrm{H}^{+},{ }^{c} \mathrm{Ca}^{2+}+2 \mathrm{XOH} \leftrightarrow\left(\mathrm{XO}^{-}\right)_{2}^{-}-\mathrm{Ca}^{2+}+2 \mathrm{H}^{+} .{ }^{d} \mathrm{Ca}^{2+}+\mathrm{XOH}^{2}$ $\rightarrow \mathrm{XOCa}^{+}+\mathrm{H}^{+}$. ${ }^{e}$ Nonelectrostatic model.

for the inner-sphere complex. The adsorption constants for each set of data are presented in columns 8 and 9 of Table V.

For the NEM, only one complexation reaction

$$
\mathrm{Ca}^{2+}+\mathrm{XOH} \leftrightarrow \mathrm{XOCa}^{+}+\mathrm{H}^{+}
$$

was required to represent the sorption of $\mathrm{Ca}$ on the $\mathrm{Fe}_{2} \mathrm{O}_{3} \cdot \mathrm{H}_{2} \mathrm{O}(\mathrm{am})$ (column 10 of Table $\mathrm{V}$ ).

The TLM and NEM surface-complexation constants for different initial $\mathrm{Ca}$ concentrations and ionic strengths varied by as much as $1 \mathrm{log}$ unit and thus were neither constant nor "intrinsic" [as described by Sposito (9) and Westall and Hohl (18)]. Previous researchers have suggested that this variation in adsorption constants is related to surface coverage and reflects the heterogeneity of the surface, which causes the metal ion to be adsorbed to less and less energetic sites as the surface coverage increases (42). That surface sites and their affinities vary would appear to be reasonable for crystalline oxides such as goethite, because different crystal faces with different surface energies and site characteristics (9) are exposed and because the crystalline surfaces have pits, edges, and other discontinuities as a result of surface defects (42). In fact, Vanek and Jedinakova (43), who investigated the sorption of $\mathrm{Ba}$ on goethite $(\alpha-\mathrm{FeOOH})$ over a range in $\mathrm{Fe} / \mathrm{Ba}$ ratios, observed that the strength of sorption of $\mathrm{Ba}$ varied with surface coverage. However, amorphous solids such as $\mathrm{Fe}_{2} \mathrm{O}_{3} \cdot \mathrm{H}_{2} \mathrm{O}(\mathrm{am})$ appear to be characterized by a larger number of low-affinity sites (44) and a small number of high-affinity sites (45). Linear regression analysis (46) of the $\log * K$ values for the various surface complexes indicated that neither surface coverage, initial $\mathrm{Ca}$ concentration, nor ionic strength, whether alone or in combination, could explained the observed variability.

These results illustrate the fact that single-element models that assume a single binding energy (i.e., conformation to a Langmuir isotherm) cannot adequately describe sorption over a range in surface coverage for sorbate-sorbent pairs that conform to a Freundlich isotherm as a result of site heterogeneity rather than electrostatic effects (47). Even though the experimental data suggested that the surface was heterogeneous with regard to $\mathrm{Ca}$ adsorption, a single-site model was used to model the individual $\mathrm{Ca}$ and $\mathrm{Cd}$ adsorption data and the combined $\mathrm{Cd}-$ $\mathrm{Ca}$ adsorption data. Although it is possible that concentration-independent $\mathrm{Ca}$ adsorption constants could be derived by using a multisite model, the single-site model was used because there is no consensus on how best to represent surface heterogeneity or on how this heterog. eneity affects competition. The multisite model has been used by Dzombak and Morel $(48,49)$, to successfully model cation sorption on oxides.

Binary-Element Adsorption. 'To evaluate the effectiveness of the TLM and NEM in predicting the measured competition, the binary-element experiments with $\mathrm{Cd}$ and $\mathrm{Ca}$ were modeled using different hypothesized surface reactions and combinations of surface reactions. For each representation of the surface reactions, the $2.4 \mathrm{mM} \mathrm{Ca}$ constants in Table $\mathrm{V}$ for $0.1 \mathrm{M} \mathrm{NaNO}_{3}$ were used to calculate the effects of $\mathrm{Ca}$ adsorption, because the $\mathrm{Ca}$ concentration in the competition experiments $(2.5 \mathrm{mM})$ was close to this value. The range in Ca constants in Table $V$ for each surface reaction was used to evaluate the sensitivity of the predicted Cd sorption to this variability. For each representation of the surface reactions, the $\mathrm{Cd}$ adsorption constants for $10^{-6} \mathrm{M} \mathrm{Cd}$ at $I=0.1 \mathrm{M}$ were used to calculate the $\mathrm{Cd}$ adsorption.

Regardless of which set of $\mathrm{Ca}$ adsorption constants was used to represent the $\mathrm{Ca}$ adsorption, when the inner-sphere complex for $\mathrm{Cd}$ adsorption was used in combination with only outer-sphere complexes for $\mathrm{Ca}$ (columns 6 and 7 of Table V), no competition was calculated and the adsorption curve predicted was identical with that for cadmium adsorption alone (Figure 5). Variation of the Ca outersphere adsorption constants within the range noted in Table $\mathrm{V}$ resulted in no more than a $1 \%$ difference between the predicted $\mathrm{Cd}$ sorption and that shown in Figure 5. The lack of competition between $\mathrm{Cd}$ and $\mathrm{Ca}$ and the insensitivity of $\mathrm{Cd}$ adsorption to variation in the $\mathrm{Ca}$ constants were not unexpected because, within the model, these two elements were placed in different planes with respect to the surface. Adsorbed $\mathrm{Ca}$, because of its location in the more remote $\beta$-plane, cannot induce a mass-action effect on $\mathrm{Cd}$ in the surface or o-plane. The calculated effects are solely electrostatic and therefore minimal.

Use of outer-sphere complexes for both $\mathrm{Cd}$ and $\mathrm{Cd}$ (columns 6 and 7 of Table $V$ ) resulted in prediction of more competition than was observed (Figure 5). The Cd adsorption was very sensitive to variation in the Ca constants. In fact, when the $0.764 \mathrm{mM}$ Ca constant was used to represent $\mathrm{Ca}$ adsorption, the predicted $\mathrm{Cd}$ adsorption was close to the measured sorption. The similarity in shape of the observed and predicted adsorption edges when outer-sphere complexes are used for both $\mathrm{Cd}$ and $\mathrm{Ca}$ suggests that this representation in the TLM was more accurate than the previous TLM representation. The fact that the competition data were better represented when the outer-sphere complexes were assumed for both $\mathrm{Cd}$ and $\mathrm{Ca}$ would be consistent with competition being driven by mass action rather than electrostatic effects. In other 


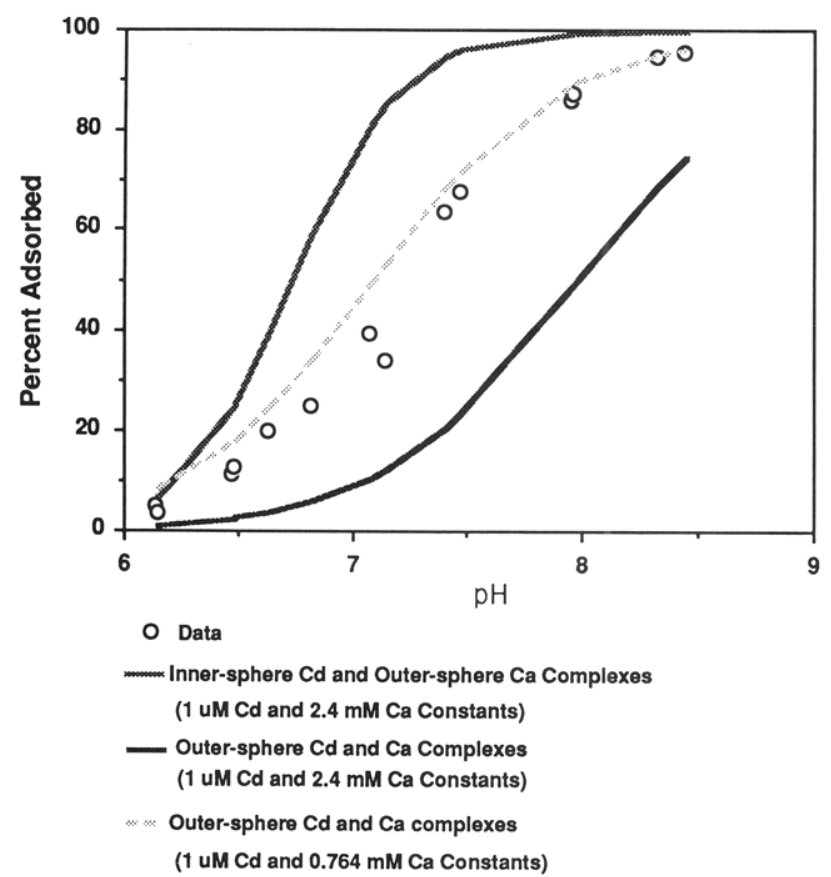

Figure 5. Comparison of experimental data for Cd adsorption in the presence of $\mathrm{Ca}$ with that predicted by TLM using various combinations of surface reactions. Experimental conditions are $10^{-6} \mathrm{M}$ Cd and 2.5 $\mathrm{mM} \mathrm{Ca}$ with $0.87 \mathrm{mM} \mathrm{Fe}$ in $0.1 \mathrm{M} \mathrm{NaNO}_{3}$.

modeling studies where the competing ions have been assumed to occupy the same plane to to compete for the same surface sites, the amount of competition predicted was also excessive $(14,42,50)$.

The previous TLM calculations indicated that the competitive effect of $\mathrm{Ca}$ on $\mathrm{Cd}$ cannot be reproduced unless at least some of the $\mathrm{Ca}$ is allowed to adsorb within the same plane as $\mathrm{Cd}$ and thus to compete by means of mass action. In an attempt to derive a TLM that better represented the competition data, it was hypothesized that the $\mathrm{Ca}$ formed a combination of inner- and outer-sphere complexes and $\mathrm{Cd}$ formed only an inner-sphere complex. In this representation, the inner-sphere $\mathrm{Ca}$ and $\mathrm{Cd}$ complexes would account for the mass-action competition between the $\mathrm{Cd}$ and $\mathrm{Ca}$ on mutually accessible sites and the outer-sphere $\mathrm{Ca}$ complex would account for the additional $\mathrm{Ca}$ sorption and the variation in $\mathrm{Ca}$ adsorption with ionic strength.

The $\mathrm{Cd}$ adsorption predicted in the $\mathrm{Ca}-\mathrm{Ca}$ experiments using the inner-sphere complex for $\mathrm{Cd}$ and a combination of inner- and outer-sphere complexes for Ca in the TLM (columns 8 and 9 of Table V) was in good agreement with the experimental data at $I=0.5 \mathrm{M}$ (Figure $6 \mathrm{a}$ ) and $\mathrm{I}=$ $0.1 \mathrm{M}$ (Figure $6 \mathrm{~b}$ ) but deviated from the experimental results at the lowest ionic strength, $I=0.005 \mathrm{M}$ (Figure $6 \mathrm{c})$. For all three ionic strengths, the sorption edge predicted by the TLM was steeper than the measured sorption edge. In contrast to the other TLM representations, when the $\mathrm{Ca}$ adsorption constants were varied over the range shown in Table $\mathrm{V}$, the predicted $\mathrm{Cd}$ adsorption did not differ by more than $2 \%$ from that shown in Figure 6.

Like the previous TLM representation, the NEM model also provided predictions of $\mathrm{Cd}\left(10^{-6} \mathrm{M}\right)$ adsorption in the presence of $\mathrm{Ca}(2.5 \mathrm{mM})$ that were close to the experimental results for the two highest ionic strengths (Figure $7 \mathrm{a}, \mathrm{b})$ and less satisfactory at the lowest ionic strength (Figure 7c). When the NEM adsorption constant for Ca was varied over the range given in Table $\mathrm{V}$, the predicted $\mathrm{Cd}$ adsorption did not differ from that shown in Figure 7 by more than $1 \%$. The very close agreement between the observed and predicted Cd adsorption at the two
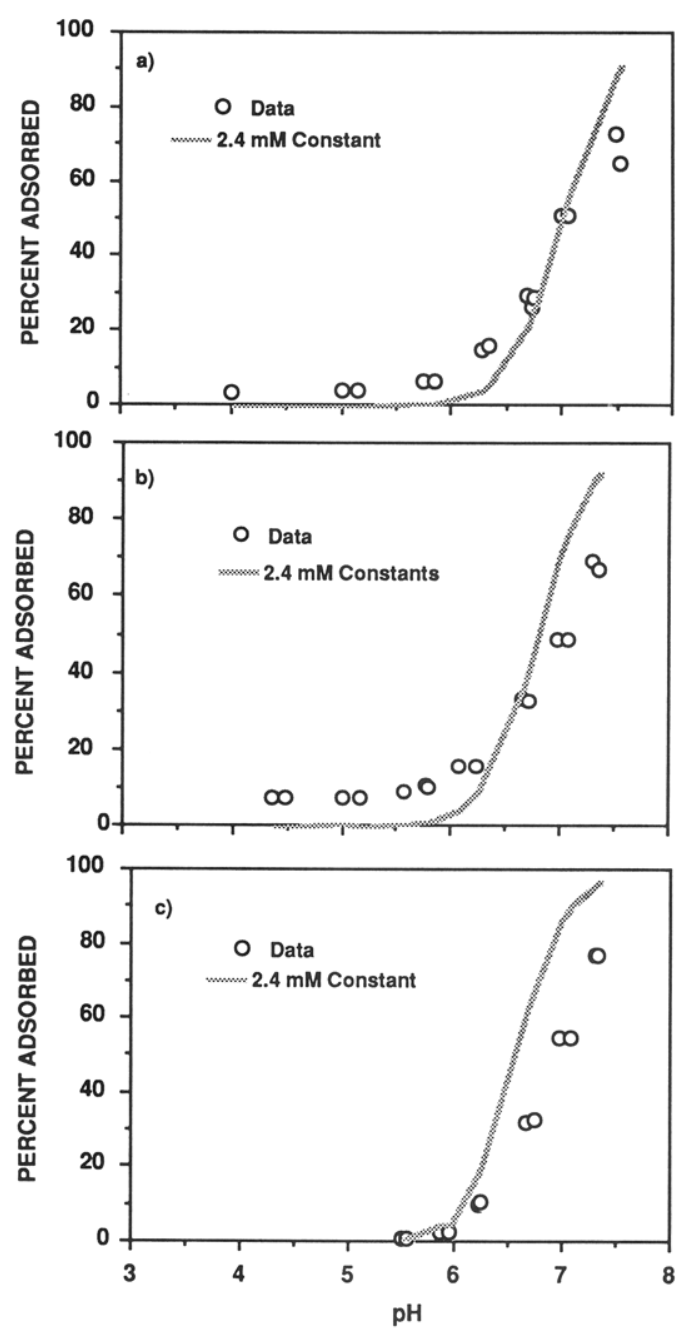

Figure 6. Comparison of experimental data for Cd adsorption in the presence of $\mathrm{Ca}$ with that predicted by TLM using inner- and outersphere adsorption constants for $\mathrm{Ca}$ and inner-sphere adsorption constant for Cd. Experimental conditions are $10^{-6} \mathrm{M} \mathrm{Cd}$ and $2.5 \mathrm{mM} \mathrm{Ca}$ with $0.87 \mathrm{mM} \mathrm{Fe}$. (a) $\mathrm{I}=0.5 \mathrm{M}$. (b) $I=0.1 \mathrm{M}$. (c) $I=0.005 \mathrm{M}$.

highest ionic strengths (Figure 7a,b), while not substantially better than that with the TLM, had special meaning because this model is simple, employing only one surface complex for $\mathrm{Ca}$, one for $\mathrm{Cd}$, and no electrostatics. The NEM calculations showed that the $\mathrm{Cd}-\mathrm{Ca}$ competition was consistent with a mass-action effect between the $\mathrm{Ca}$ and $\mathrm{Cd}$ on mutually accessible surface sites. The shape of the $\mathrm{Cd}-\mathrm{Ca}$ sorption edges predicted from the NEM (Figure $7 \mathrm{a}-\mathrm{c}$ ) was much closer to that of the measured $\mathrm{Cd}-\mathrm{Ca}$ adsorption edge than the $\mathrm{Cd}-\mathrm{Ca}$ adsorption edges predicted by using the TLM were (Figure $6 \mathrm{a}-\mathrm{c}$ ).

These modeling results imply that the $\mathrm{Cd}-\mathrm{Ca}$ competition is due to a mass-action effect between the $\mathrm{Cd}$ and $\mathrm{Ca}$, and that electrostatics are of little importance. Additionally, the lack of appreciable ionic strength effect on the $\mathrm{Cd}-\mathrm{Ca}$ competition (Figure $3 \mathrm{~b}$ ) suggests that $\mathrm{Na}$ is not a significant competitor for the sites that are mutually accessible to $\mathrm{Cd}$ and $\mathrm{Ca}$. The electrostatic component of the TLM makes the predicted adsorption edge rise more rapidly with $\mathrm{pH}$ than was observed. Electrostatic effects on the adsorption of cations should be important only when the surface becomes saturated with the cations and the surface charge is reversed (34).

Implications of Binary-Element Modeling. Surface-complexation models have been used with varying success to predict multielement sorption using adsorption constants calculated from single-element adsorption ex- 

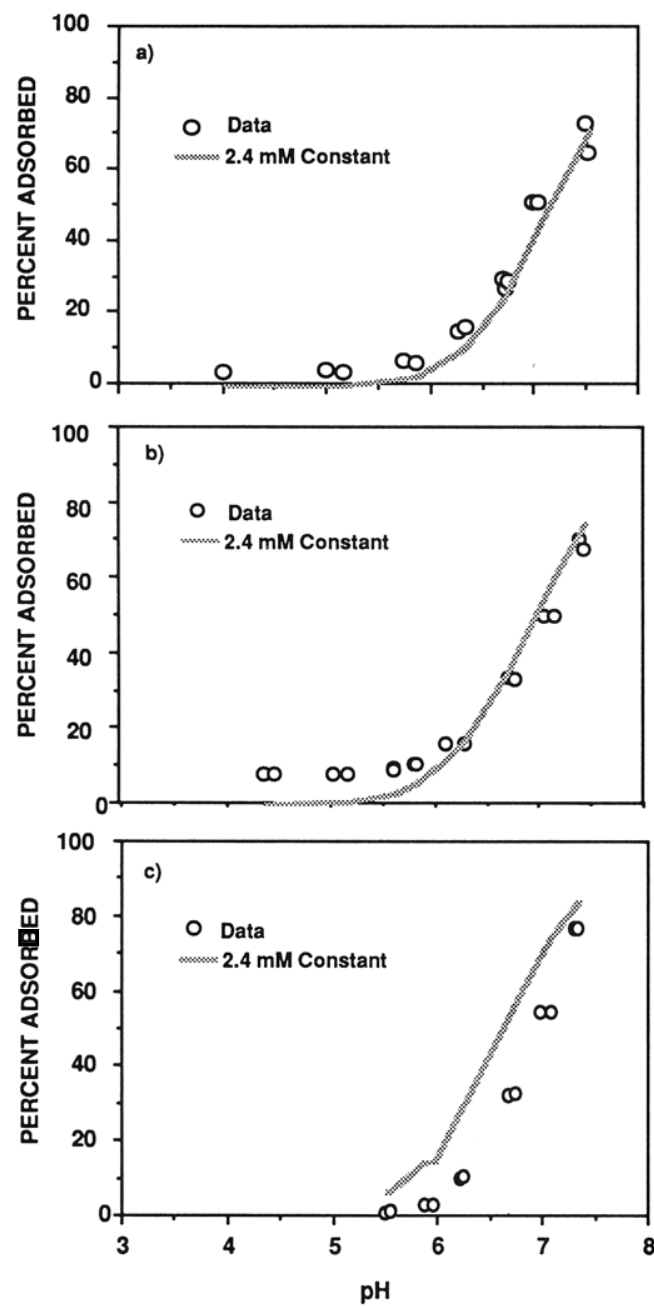

Figure 7. Comparison of experimental data for $\mathrm{Cd}$ adsorption in presence of $\mathrm{Ca}$ with that predicted by NEM. Experimental conditions are $10^{-6} \mathrm{M} \mathrm{Cd}$ and $2.5 \mathrm{mM} \mathrm{Ca}$ with $0.87 \mathrm{mM} \mathrm{Fe}$. (a) $I=0.5 \mathrm{M}$. (b) $I=0.1 \mathrm{M}$. (c) $I=0.005 \mathrm{M}$.

periments. Single-element adsorption constants have been used to qualitatively predict the adsorption of $\mathrm{CrO}_{4}{ }^{2-}$ in the presence of $\mathrm{SO}_{4}{ }^{2-}$ and dissolved inorganic carbon on $\mathrm{Fe}_{2} \mathrm{O}_{3} \cdot \mathrm{H}_{2} \mathrm{O}(\mathrm{am})(22)$ and oxide-containing subsurface soils (23). Also, Balistrieri and Murray (3) modeled the competitive effect of $\mathrm{Mg}$ on $\mathrm{Cd}$ adsorption onto goethite in artificial seawater using this approach. Their modeling results were consistent with the results shown here, in that the best approximation to the competition data using the TLM was found for high ionic strengths $(I=0.5 \mathrm{M})$, when inner-sphere complexes for $\mathrm{Mg}$ and $\mathrm{Cd}$ would predominate (e.g., Figure 6a). In contrast, Goldberg and Traina (50) found that constant-capacitance surface-complexation constants fit to the single-element sorption data predicted too much competition between the strongly sorbing anion orthophosphate and the anions selenite and silicate on goethite. Benjamin (42) found that single-element sorption constants representing outer-sphere complexes resulted in overprediction of the competitive sorption of $\mathrm{Cd}$ in the presence of $\mathrm{Cu}, \mathrm{Zn}$, and $\mathrm{Pb}$ on $\mathrm{Fe}_{2} \mathrm{O}_{3} \cdot \mathrm{H}_{2} \mathrm{O}(\mathrm{am})$.

Goldberg and Traina (50) argued that it was not possible to closely predict binary-element sorption data from single-element sorption constants because of either site heterogeneity or incorrect estimates of the activity coefficient of the surface complexes. Site heterogeneity could cause some of the sites to selectively adsorb one element over the other. Furthermore, as a result of competition, an element could become sorbed to less energetic sites than were encountered in the single-element sorption. Because the electrostatic term in the TLM can be considered as the sorbed-phase activity coefficient corrected for the charge of the sorbed species (9), an inaccurate representation of this term could make it impossible to accurately predict the degree of competition. Other factors not explicitly accounted for by the electrostatic term may also influence the sorbate surface's activity coefficients. Chu and Sposito (51) argued that, for this reason, binary exchange data are not sufficient to model ternary exchange and that some information on the ternary exchange is necessary to accurately estimate the activity coefficients. However, their example indicated that these additional data are not always required.

To avoid the problem of how to represent surface heterogeneity and surface activity coefficients, Goldberg and Traina (50) recommended that constants be fitted for each of the two elements by using the competition data. This approach is reasonable if the objectives of the model are to predict competition for similar experimental conditions. The new constants would have limited value for predicting competition for other solution compositions. For example, these constants would not accurately predict the single-element sorption data. Furthermore, this approach would require that constant be derived for every solution composition of interest. If the objective of the modeling is, instead, to develop an approach for predicting multielement adsorption from basic data such as that describing the adsorption of the single elements, then another approach must be developed.

The ability of the TLM with a combination of inner- and outer-sphere surface complexes and the NEM to predict the $\mathrm{Cd}-\mathrm{Ca}$ competition at the highest ionic strengths implies that a credible modeling approach using single-element adsorption constants could be developed. These two models are not overly sensitive to variations in the adsorption constants of the single elements, suggesting that such a model could also be quite stable. In addition, the fact that both the TLM and NEM were able to predict the competition at the highest ionic strengths with a set of constants fit to the single-element sorption data suggests that, at ionic strengths greather than $0.1 \mathrm{M}$, the Cd adsorption is not shifted to lower energy sites by competition with Ca. Finally, these results suggest that surface heterogeneity may not be an important factor when the ionic strength is approximately $0.1 \mathrm{M}$ or more. However, it is possible that site heterogeneity on $\mathrm{Fe}_{2} \mathrm{O}_{3} \cdot \mathrm{H}_{2} \mathrm{O}(\mathrm{am})$ could account for both models' inability to predict the $\mathrm{Cd}-\mathrm{Ca}$ competition in the lowest ionic strength solution.

\section{Conclusions}

The binary-element experiments indicate that, at typical environmental concentrations, the alkaline-earth elements $\mathrm{Mg}, \mathrm{Sr}$, and $\mathrm{Ba}$ will have little effect on the adsorption of $\mathrm{Cd}$ and similar elements on $\mathrm{Fe}_{2} \mathrm{O}_{3} \cdot \mathrm{H}_{2} \mathrm{O}(\mathrm{am})$. Solubility limitations in soil and groundwater systems will prevent $\mathrm{Sr}$ and $\mathrm{Ba}$ from reaching concentrations high enough to allow them to compete with $\mathrm{Cd}$ on iron oxides. However, competitive adsorption of $\mathrm{Cd}$ with $\mathrm{Ca}$ can be important in soil or groundwater. Competition between $\mathrm{Cd}$ and $\mathrm{Ca}$ was observed over ranges of $\mathrm{Ca}$ concentrations and $\mathrm{pH}$ that are environmentally important. When competition occurs, the percentage of $\mathrm{Cd}$ adsorbed could fall by $20 \%$ or more below that for $\mathrm{Cd}$ alone, depending on the $\mathrm{pH}$ and on the concentrations of $\mathrm{Cd}$ and $\mathrm{Ca}$ in the soil solutions, groundwater, or leachate.

Application of electrostatic (TLM) and nonelectrostatic (NEM) surface-complexation models showed that the competitive effect was consistent with a mass-action effect 
between $\mathrm{Ca}$ and $\mathrm{Cd}$ on mutually accessible surface sites. The TLM accurately represented the results of the competition experiments in the high $(I=0.5 \mathrm{M})$ and medium $(I=0.1 \mathrm{M})$ ionic strength solutions only when a combination of inner- and outer-sphere surface complexes for $\mathrm{Ca}$ and an inner-sphere complex for $\mathrm{Cd}$ were included in the model. The NEM, which includes only one adsorption plane, one surface complex each for $\mathrm{Cd}$ and $\mathrm{Ca}$, and no electrostatics, provided predictions of the $\mathrm{Cd}-\mathrm{Ca}$ competition at high and medium ionic strengths that agreed with the experimental data at least as well as the predictions made by the TLM. Neither model accurately represented the amount of adsorption at the lowest ionic strength ( $I$ $=0.005 \mathrm{M}$ ), which is the ionic strength most relevant to natural soil solutions or groundwater. No reason for this discrepancy could be identified. Even though the singleelement sorption constants of $\mathrm{Ca}$ for initial $\mathrm{Ca}$ concentrations ranging from 2 orders of magnitude and ionic strengths varying over 3 orders of magnitude differed by as much as $1 \log$ unit, the predicted Cd sorption was not sensitive to this range in the adsorption constants, indicating that both these models were very stable. At all ionic strengths, the NEM simulated the shape of the combined $\mathrm{Cd}-\mathrm{Ca}$ adsorption edges better than the TLM. These results show that the more complex electrostatic model does not provide calculations of $\mathrm{Cd}-\mathrm{Ca}$ competition that are improved sufficiently to warrant its application over the nonelectrostatic model. Rather, our evaluation has shown that the NEM using single-element sorption constants can effectively model multielement adsorption for the conditions used in this study. Given the limited range of experimental conditions evaluated, additional investigations are clearly needed to determine whether these two modeling approaches can expediently and accurately predict multielement sorption equilibria under the broad range of solute, contaminant, and electrolyte conditions found in natural waters.

\section{Acknowledgments}

Dr. C. Hostetler and Mr. R. Erikson demonstrated to us the usefulness of the NEM for solute adsorption calculations on $\mathrm{Fe}_{2} \mathrm{O}_{3} \cdot \mathrm{H}_{2} \mathrm{O}(\mathrm{am})$. In addition, we would like to thank Ms. C. Peyton for performing the initial modeling analyses.

Registry No. Cd, 7440-43-9; $\mathrm{Fe}_{2} \mathrm{O}_{3}, 1309-37-1 ; \mathrm{Ca}, 7440-70-2$; $\mathrm{Mg}, 7439-95-4 ; \mathrm{Sr}, 7440-24-6$; $\mathrm{Ba}, 7440-39-3$.

\section{Literature Cited}

(1) Davis, J. A.; Leckie, J. O. J. Colloid Interface Sci. 1978 67, 90-107.

(2) Benjamin, M. M.; Bloom, N. S. In Adsorption from Aqueous Systems; Tewari, P. H., Ed.; Plenum: New York, 1981

(3) Balistrieri, L. S.; Murray, J. W. Geochim. Cosmochim. Acta $1982,46,1253-1265$.

(4) Loganathan, P.; Burau, R. G. Geochim. Cosmochim. Acta $1973,37,1277-1293$.

(5) Murray, J. W. Geochim. Cosmochim. Acta 1975, 39, $505-519$.

(6) Loganathan, P.; Burau, R. G.; Fuerstenau, D. W. Soil Sci. Soc. Am. J. 1977, 41, 57-62.

(7) McKenzie, R. M. Aust. J. Soil Res, 1980, 18, 61-73.

(8) Jenne, E. A. Adv. Chem. Ser. 1968, No. 73, 337-387.

(9) Sposito, G. The Surface Chemistry of Soils; Oxford University Press: New York, 1984; p 234.

(10) Rai, D.; Zachara, J. M.; Schwab, A. P.; Schmidt, R. L.; Girvin, D. C.; Rogers, J. E. Chemical Attenuation Rates, Coefficients, and Constants in Leachate Migration. EA3356; prepared for the Electric Power Research Institute; Battelle, Pacific Northwest Laboratories; Richland, WA, 1984.
(11) Sigg, L. In Aquatic Surface Chemistry; Stumm, W., Ed.; John Wiley and Sons: New York, 1987.

(12) Kent, D. B.; Tripathi, V. S.; Ball, N. B.; Leckie, J. O. Surface Complexation Modeling of Radionuclide Adsorption in Subsurface Environments; NUREG/CR-4897, SAND 867175; U.S. Nuclear Regulatory Commission: Washington, DC; 1988.

(13) Benjamin, M. M.; Leckie, J. O. In Contaminants and Sediments; Baker, R. A., Ed.; Ann Arbor Science: Ann Arbor, MI, 1980; Vol. 2, Chapter 16.

(14) Benjamin, M. M.; Leckie, J. O. J. Colloid Interface Sci. 1981, 79, 209-221.

(15) Zasoski, R. J.; Burau, R. G. Soil Sci. Soc. Am. J. 1988, 52, 81-87.

(16) Swallow, K. C.; Hume, D. N.; Morel, F. M. M. Environ. Sci. Technol. 1980, 14, 1326-1331.

(17) Dempsey, B. A.; Singer, P. C. In Contaminants and Sediments; Baker, R. A., Ed.; Ann Arbor Science: Ann Arbor, MI, 1980.

(18) Westall, J.; Hohl, H. Adv. Colloid Interface Sci. 1980, 12, 265-294.

(19) Stumm, W.; Hohl, H.; Dalang, F. Croat. Chem. Acta 1976, $43,491$.

(20) Hayes, K. F.; Leckie, J. O. J. Colloid Interface Sci. 1987, $115,564-572$

(21) Balistrieri, L. S.; Murray, J. W. Am. J. Sci. 1981, 281, 788-806.

(22) Zachara, J. M.; Girvin, D. C.; Schmidt, R. L.; Resch, C. T. Environ. Sci. Technol. 1987, 21, 589-594.

(23) Zachara, J. M.; Ainsworth, C. C.; Cowan, C. E.; Resch, C. T. Soil Sci. Soc. Am. J. 1989, 53, 418-428.

(24) Girvin, D. C.; Ames, L. L.; McGarrah, J. E. J. Colloid Interface Sci., in press.

(25) Westall, J. FITEQL, A Computer Program for Determination of Equilibrium Constants from Experimental Data; Version 1.2, Report 82-01; Department of Chemistry, Oregon State University: Corvallis, OR, 1982.

(26) Westall, J. FITEQL, A Computer Program for Determination of Equilibrium Constants from Experimental Data; Version 2.0, Report 82-02; Department of Chemistry, Oregon State University: Corvallis, OR, 1982

(27) Davis, J. A. Ph.D. Dissertation, Stanford University, 1978.

(28) Bell, J. W.; Nordstrom, D. K.; Jenne, E. A. Additional and Revised Thermodynamic Data and Computer Code for WATEQ2-A Computerized Chemical Model for Trace and Major Element Speciation and Mineral Equilibria of Natural Waters; Water Resources Investigations No. 78116; U.S. Geological Survey: Menlo Park, CA, 1980.

(29) Krupka, K. M.; Erikson, R. L.; Mattigod, S. V.; Schramke, J. A.; Cowan, C. E.; Eary, L. E.; Morrey, J. R.; Schmidt, R. L.; Zachara, J. M. A Guide to the Thermodynamic Data in the FASTCHEM Package. Prepared for the Electric Power Research Institute; Battelle, Pacific Northwest Laboratories, Richland, WA, 1988.

(30) Benjamin, M. M.; Leckie, J. O. Environ. Sci. Technol. 1982, 16, 162-170

(31) Farley, K. J.; Dzombak, D. A.; Morel, F. M. M. J. Colloid Interface Sci. 1985, 106, 226-242.

(32) Kinniburgh, D. G.; Syers, J. K.; Jackson, M. L. Soil. Sci. Soc. Am. Proc. 1975, 39, 464-470.

(33) Kinniburgh, D. G.; Jackson, M. L.; Syers, J. K. Soil Sci. Soc. Am. J. 1976, 40, 796-799.

(34) Dzombak, D. A. Ph.D. Dissertation, Massachusetts Institute of Technology, 1986.

(35) Cederberg, G. A.; Street, R. L.; Leckie, J. O. Water Resour. Res. 1985, 21, 1095-1104.

(36) Catts, J. G.; Langmuir, D. Appl. Geochem. 1986, 1, 255-264.

(37) Davis, A.; Runnells, D. D. Appl. Geochem. 1987, 2, 231-241.

(38) Stumm, W.; Kimmert, R.; Sigg, L. Croat. Chem. Acta 1980, $53,291$.

(39) Schindler, P. W.; Stumm, W. In Aquatic Surface Chemistry; Stumm, W., Ed.; Wiley Interscience: New York, 1987.

(40) Posselt, H. S.; Anderson, F. J.; Weber, W. J., Jr. Environ. Sci. Technol. 1968, 2, 1087-1093.

(41) Balistrieri, L. S.; Murray, J. W. In Chemical Modeling in Aqueous Systems; Jenne, E. A., Ed.; ACS Symposium Series 
93; American Chemical Society: Washington, DC, 1979; pp 275-298.

(42) Benjamin, M. M. Ph.D. Dissertation, Stanford University, 1979.

(43) Vanek, K.; Jedinakova, V. J. Colloid Interface Sci. 1986, $111,276-279$.

(44) Kinniburgh, D. G.; Jackson, M. L. In Adsorption of Inorganics at Solid-Liquid Interfaces; Anderson, M. A., Rubin, A. J., Eds.; Ann Arbor Science: Ann Arbor, MI, 1981.

(45) Kinniburgh, D. G.; Baker, J. A.; Whitfield, M. J. Colloid Interface Sci. 1983, 95, 370-384.

(46) Snedecor, G. W.: Cochran, W. G. Statistical Methods, 6th ed.; The Iowa State University Press: Ames, IA, 1976.

(47) Westall, J. C. In Aquatic Surface Chemistry; Stumm, W. Ed.; John Wiley and Sons: New York, 1987; Chapter 1.
(48) Dzombak, D. A.; Morel, F. M. M. J. Colloid. Interface Sci. $1986,112,588$.

(49) Dzombak, D. A.; Morel, F. M. M. J. Hydraul. Eng. 1987, 113,430 .

(50) Goldberg, S.; Traina, S. J. Soil Sci. Soc. Am. J. 1987, 51, 929-932.

(51) Chu, S.-Y.; Sposito, G. Soil Sci. Soc. Am. J. 1981, 45, $1084-1089$.

Received for review January 18, 1989. Revised manuscript received June 18, 1990. Accepted October 10, 1990. This research was funded by the Electric Power Research Institute, Inc. (EPRI) under Contract RP2485-03, Chemical Attenuation Studies, to Battelle, Pacific Northwest Laboratories.

\section{Brominating Activity of the Seaweed Ascophyllum nodosum: Impact on the Biosphere}

\section{Ron Wever, " Michiel G. M. Tromp, Bea E. Krenn, Abdoeljallal Marjani, and Mauritz Van Tol}

E. C. Slater Institute for Biochemical Research and Biotechnological Center, University of Amsterdam, Plantage Muidergracht 12, 1018 TV Amsterdam, the Netherlands

Macroalgae are an important source of volatile halogenated organic compounds, such as bromoform and dibromomethane. The mechanism by which these compounds are formed is still elusive. We report that the brown seaweeds Laminaria saccharina, Laminaria digitata, Fucus vesiculosis, Pelvetia canaliculata, and Ascophyllum nodosum and the red seaweeds Chondrus crispus and Plocamium hamatum contain bromoperoxidases. The intact plants are able to brominate exogeneous organic compounds when $\mathrm{H}_{2} \mathrm{O}_{2}$ and $\mathrm{Br}^{-}$are added to seawater. Further, we show that the brominating activity of the brown macroalga $A$. nodosum, which contains a vanadium bromoperoxidase located on the thallus surface, occurs when the plant is exposed to light and not in the dark. The rate of bromination of exogenous organic compounds in seawater by this plant is $68 \mathrm{nmol}$ (g of wet alga) $)^{-1} \mathrm{~h}^{-1}$. $\mathrm{HOBr}$ is a strong biocidal agent and we propose that the formation of $\mathrm{HOBr}$ by this seaweed is part of a host defense system.

\section{Introduction}

There is great current interest in the formation of organohalides produced by both anthropogenic activities and biological sources. Recently, it has been suggested (1) that chemical reactions occur in the troposphere at polar sunrise in the Arctic. In one of these processes ozone destruction occurs at ground level, which may be connected to the formation of bromoform and aerosol enrichment with bromine of biological origin (2). According to Sturges and Barrie (2), inorganic bromine in Arctic aerosols may originate from photochemical conversion of marine organic bromine. Measurements (3) of atmospheric bromoform at Point Barrow, AK, show that the presence of this compound is seasonal: bromoform concentrations are maximal in winter and minimal in summer. Similarly, the bromine content of Arctic aerosols at Point Barrow, Alert (Canadian Arctic), and Spitsbergen shows an annual sharp maximum between February and May at concentrations that are the highest in the world $(2,4,5)$. There is substantial evidence that the source of the bromine-containing particles and bromoform is biogenic and it has been speculated that the formation is due to the enzymic activity of vanadium bromoperoxidases present in brown seaweeds that grow in the Arctic Ocean (6). Indeed, Dyrssen and Fogelquist $(7,8)$ showed that bromoform is present in the Arctic Ocean near Spitsbergen and the data clearly indicate that algal belts are responsible for its production. It is wellknown that brown seaweeds (Ascophyllum nodosum, Fucus vesiculosis), red seaweeds (Gigartina stellata), and marine green seaweeds (Enteromorpha linza, Ulva lacta) release large quantities of brominated methanes such as bromoform and dibromomethane into the marine ecosystem (9).

Recently, a group of vanadium-containing bromoperoxidases has been discovered in a number of brown seaweeds (Fucus distichus, Alaria esculenta, Laminaria saccharina, Chorda filum) and in red seaweeds (Ceramium rubrum and Corallina pilulifera) (10-14). In the presence of hydrogen peroxide and bromide these enzymes (15) produce free hypobromous acid and bromine. The peroxidases are assumed to be involved in the biosynthesis of the halogenated metabolites by bromination of nucleophilic acceptors. As has been shown by Theiler et al. (16) for the marine red alga Bonnemaisonia hamifera and by Burreson et al. (17) for the red alga Asparagopsis taxiformis, the acceptors are probably carboxy methyl ketones, which are brominated by purified bromoperoxidase and then decay to form brominated methanes. However, whether similar acceptors also exist in brown or other red seaweeds is not known and other pathways may exist.

The brown seaweed $A$. nodosum (knotted wrack), which grows in large quantities in the North Atlantic and western Russian polar seas (18), contains two vanadium bromoperoxidases (19). One is located inside the so-called fruiting bodies and its presence shows a seasonal cycle (6). The other enzyme is located on the surface of the fruiting bodies and may be extracellular (19). This raises the interesting possibility that these seaweeds also release free hypobromous acid and bromine in seawater. Reaction of these bromine species with dissolved organic matter in seawater may well result in the formation of bromoform and other brominated compounds, and thus the origin of bromoform may be an indirect result of the formation of $\mathrm{HOBr}$ by seaweeds. In fact, Sauvageau (20) already re- 